\title{
FORUM
}

\section{INTEGRATED PEST MANAGEMENT: A GLOBAL REALITY?}

\author{
Marcos Kogan and Waheed I. Bajwa \\ Integrated Plant Protection Center \\ Oregon State University \\ 2040 Cordley Hall, Corvallis Oregon, 97331, USA
}

An. Soc. Entomol. Brasil 28(1): 1-25 (1999)

Manejo Integrado de Pragas: Uma Realidade Mundial?

RESUMO - A expressão "Manejo Integrado de Pragas" (MIP ou Integrated Pest Management - IPM - em inglês) está completando 28 anos desde que apareceu impressa pela primeira vez. Desde então manejo integrado ou controle integrado de pragas tornou-se o paradigma preferencial para as atividades que visam a atenuar o impacto de pragas - doenças de plantas, ervas daninhas e animais vertebrados ou invertebrados - na produção agrícola, na saúde humana e veterinária, e nas estruturas urbanas e rurais. Apesar da aceitação quase universal do conceito de manejo integrado, sua aplicação prática é ainda restrita variando grandemente de acordo com a região geopolítica, a natureza do cultivo agrícola e, principalmente, com o empenho e apoio governamentais a programas que visam a estimular a adoção do manejo integrado. Uma avaliação objetiva do sucesso da incorporação de programas de MIP nas práticas agrícolas é difícil devido a: a) falta de critérios rigorosos que distinguem um programa de MIP de quaisquer outras atividades tradicionais de controle de pragas, b) falta de um consenso universal sobre uma definição de MIP, e c) carência de levantamentos quantitativos de áreas de cultivo sob programas de MIP. Em alguns círculos, a medida do sucesso do MIP tem sido a porcentagem de redução no uso de pesticidas. No entanto, essa medida, na ausência de outros critérios, é inadequada pois, em algumas partes do mundo a introdução do MIP pode acarretar o aumento, não a diminuição no uso de pesticidas. Após procurar avaliar a expansão de programas de MIP no mundo, é essencial que se chegue a um consenso sobre critérios para medir a natureza do programa. De forma geral esses critérios dependem do nível de integração do programa, da natureza das pragas, do valor do cultivo, da disponibilidade de tecnologias alternativas e dos riscos econômicos, ambientais e sociais. Em vista da atual carência de dados e falta de critérios objetivos de avaliação, nós optamos por usar o titulo, não como uma afirmação, mas como uma asserção a ser questionada: é o Manejo Integrado de Pragas uma realidade mundial?

PALAVRAS-CHAVE: Histórico, base ecológica, proteção vegetal, táticas de controle, implementação.

ABSTRACT - The expression "Integrated Pest Management" (IPM or MIP in 
Portuguese) is completing 28 years since it first appeared in press. Since then integrated pest management or integrated pest control has become the paradigm of choice for activities that aim at attenuating the impact of all pests - plant diseases, weeds, and invertebrate or vertebrate animals - in agricultural production, in human and animal health, and in urban or rural structures. Despite the nearly universal acceptance of the concept, its practical application still is rather restricted, varying considerably among geopolitical regions, the nature of the crop, and, mainly, with the commitment and support of responsible governmental entities for programs dedicated to promote adoption of IPM. An objective assessment of the successful incorporation of IPM in agricultural practices is difficult because: a) lack of rigorous criteria to distinguish an IPM program from other traditional pest control activities, $b$ ) absence of a broadly based consensus on a definition of IPM, and c) paucity of reliable quantitative surveys of the agricultural area under IPM. Some have used the percentage of pesticide use reduction as a measure of the success of IPM. This measure, however, in the absence of other criteria, may not be appropriate for in some parts of the world introduction of IPM may lead to an increase in pesticide use, not a reduction. In our search to assess the expansion of IPM programs in the world, we concluded that it is essential to first achieve a consensus on the criteria to measure the nature of the program. In general these criteria depend on the level of IPM integration, the nature of the pests, the value of the crop, the availability of alternative control technologies, and the associated economic, environmental, and social risks. In view of the small volume of available data and in the absence of objective measurements of performance criteria, we opted to use as title for this paper an assertion to be questioned: is indeed IPM a global reality?

KEY WORDS: History, ecological basis, plant protection, control tactics, implementation.

This paper is a summary of a plenary address presented by one of us (MK) on the opening day of the XVIIth Congress of the " Sociedade Brasileira de Entomologia" or "SEB" (the Brazilian Entomological Society) held in Rio de Janeiro Brazil, August 9-14, 1998. The letter of invitation for this plenary address suggested for its title the central theme of the entire Congress, i.e., the affirmative sentence: "Integrated Pest Management: A Global Reality". In the weeks preceding the event, we carefully considered the implications of this theme and concluded that, upon agreeing on a categorical affirmation, we had little room to expand on our thoughts. Indeed, we found many tangible indicators that Integrated Pest Management (IPM) has achieved international recognition and widespread (global?) acceptance. For example: a) there are several international scientific journals exclusively dedicated to IPM, e.g., International Journal of Pest Management, Integrated Pest Management Reviews, and many others, including these Anais da SEB, in which IPM, or IPM related articles, constitute $25 \%$ or more of the contents; b) a search in "Agricola" covering the period of 1987-1997 yielded 3,070 papers published on IPM worldwide, 
exclusive of those articles in the popular press; c) in 1998, IPMnet** tabulated 49 major scientific meetings on all continents (exclusive of the hundreds of local or regional meetings dedicated to the training of IPM practitioners); d) "IPMnet NEWS" the electronic newsletter of IPMnet, in addition to being accessible via the World Wide Web (WWW), is posted electronically to recipients in 109 countries; e) IPM has a vigorous presence on the WWW, the "Database of IPM Resources" (DIR http://ippc.orst.edu/dir), also a product of IPMnet, has links to over 5,000 web pages worldwide, and DIR receives an average of 400 hits per day. Unquestionably, these are signs of the vitality of IPM and clear indicators of the global identification with the concept.

Conceivably, though, the Congress's theme might have been instead an exclamatory sentence: "IPM: A Global Reality!" In this case the organizers of the Congress would have been after a laudatory piece relating case histories that demonstrate some of the outstanding achievements of IPM in many crops around the world. Such a piece, however, would offer little novelty or provide little basis for thoughtful debate, for case histories of successful IPM have been the object of at least three books (Hansen 1987, Leslie and Cuperus 1993, Persley 1996); numerous chapters in IPM textbooks and related volumes (see http:/ /ippc.orst.edu/ipmtextbooks); and 34 chapters covering 28 crops, mostly with an IPM focus published in Annual Review of Entomology in the past 25 years. Again, these are clear indicators of the global recognition of IPM as the fundamental paradigm for crop protection in the last quarter of the XXth century. We did not think, however, that we could develop a stimulating paper based on this approach. We decided, instead, to question the validity of the theme: is IPM indeed a global reality? To answer this question we must survey what is the level of IPM adoption worldwide. Such a survey, however, does not necessarily provide a firm basis for an evaluation because there are no established performance criteria uniformly adopted to assess the status of IPM around the world. More importantly, perhaps, it must be made clear what is the IPM concept used to select those performance criteria. We, therefore, provide a brief historical assessment of the development of the IPM concept and its multiple definitions, we discuss possible indicators of the effectiveness of IPM programs and criteria to evaluate IPM adoption, and, based on those criteria we provide an assessment of IPM around the world. This background will allow us to more objectively address the question posed by the title of the paper.

\section{IPM Origins and Trajectory}

The full expression "Integrated Pest Management" (IPM) appeared in press, for the first time, 28 years ago (Kogan 1998). The scientific basis of "Integrated Pest Control" evolved over a period of about 10 years, mainly among researchers at the University of California, Berkeley and Riverside campuses. The concept was explicitly defined in 1965 at a symposium sponsored by the Food and Agriculture Organization (FAO), of the United Nations, held in Rome, Italy, with the participation of 87 delegates from 34 countries and seven international agencies (FAO 1966b). Interestingly, there were seven delegates from Latin American countries (Argentina, Bolivia, Cuba, Paraguay, Peru, and Venezuela), but none from Brazil (FAO 1966a). The concept of "Integrated Control", originally limited to the combination of chemical and biological

*IPMnet is the trademarked electronic IPM information system of the Consortium for International Crop Protection, developed in cooperation with the Oregon State University, Integrated Plant Protection Center and the North Carolina State University, National IPM Network. 
control methods (Michelbacher \& Bacon 1952), was greatly expanded in that symposium, and redefined to become synonymous with what we presently consider IPM. Thus the concept of "integration" stemmed from foundations established in the U.S.A. Concurrently, however, the concept of "Pest Management" that had been proposed by Australian ecologists in 1961 (Geier \& Clark 1961), started receiving greater recognition in the U.S.A. Publication of Geier 's Annual Review of Entomology article in 1966 (Geier 1966), a report by the US National Academy of Sciences (NAS 1969), and the proceedings of a conference held in North Carolina which included participation by the original proponents of pest management from Australia (Rabb and Guthrie 1970), provided the impetus for that recognition. The convergence of the concepts of integrated control and pest management, and the ultimate synthesis into integrated pest management, opened a new era in the protection of agricultural crops, domestic animals, stored products, public health, and the structure of human dwellings against the attack of arthropod pests, plant and animal diseases, and weeds. A more detailed account of the historical development of IPM is found in Kogan (1998).

Over the years the IPM concept evolved in diverse directions resulting in what appears to be a lack of consensus of what IPM really is. Perhaps the most controversial term of the expression is "integration". It seems, however, that the controversy is reconciled if IPM is conceived at three levels of integration: Level I - is the integration of multiple control tactics into a control strategy for individual pest species or species complexes within the same pest category, i.e., arthropods, pathogens, or weeds. The operational unit is the crop field and the ecological scale is the pest population. Level II - is the integration of multiple and interactive impacts of all pests within the crop community and the tactics for their management. The operational unit is the individual farm or multiple farms within a region and the ecological scale is the crop biotic community. Level III - is the integra- tion of multiple pests and controls within the context of the regional cropping system and surrounding natural vegetation. The operational unit is the regional agricultural production system and the ecological scale is the ecosystem (Kogan 1988; Kogan et al. 1999). Prokopy \& Croft (1994) suggested the need for a fourth level, socio-political integration, but, in our view, regulatory and other issues determined by societal demands and political actions permeate all three levels of integration and thus should not be identified as yet an additional level.

\section{Crop Protection in the Second Half of the XXth Century}

Agricultural systems in Europe and Asia at the end of World War II were severely disrupted. Total production in Europe in 1946, one year after the end of the war, was 38 percent below the production level of the prewar years. In 1948 production still was more than 10 percent lower. In Asia, although declines were not as profound, production in 1948 was about eight percent lower than in pre-war years. The war had left widespread starvation and the need to restore and possibly exceed pre-war production levels was urgent. Producers everywhere were ready to apply all available technological resources to meet the demands of peacetime markets.

A major technological breakthrough in crop protection was the discovery of the insecticidal properties of DDT by the Swiss chemist, Paul Müller, in 1939. The greatest benefits of DDT in agriculture were in the control of the Colorado potato beetle, Leptinotarsa decemlineata (Say), and other potato insect pests; the codling moth, Cydia pomonella (L.), on apples; the cotton bollworm, Helicoverpa zea (Boddie), tobacco budworm, Heliothis virescens (Fab.), and pink bollworm, Pectinophora gossypiella on cotton; and complexes of lepidopterous caterpillars on vegetable crops; as well as defoliating pests of forest trees (Ware 1986). Production for agricultural use started in 1943. Twenty years later production reached a peak at 99 
million $\mathrm{kg}$ and, until DDT was finally banned by the U.S. Environmental Protection Agency in 1973, over 1.8 billion $\mathrm{kg}$ of DDT had been used throughout the world. The success of DDT was followed by a vigorous expansion of the agrochemical industry and the registration of hundreds of new pesticides (Figure 1).

Unanticipated problems following the widespread use of insecticides soon flared up. In 1947 resitance to DDT was first detected in houseflies and in the mosquito, Culex pipiens molestus Forskal, in Italy (Brown 1958). Thereafter, documented cases of the ecological impact of the massive use of pesticides accumulated at a rapid pace (Metcalf 1986, Perkins \& Patterson 1997) and were compellingly dramatized in the books by Rachel Carlson (1962) and Robert van den Bosch (1978). The metaphor of the insecticide treadmill was documented for cotton and other crops. The ascending spiral of discov- ery and use of new and more powerful insecticides leading to the selection of ever more resistant strains of the target pests (leading to the super-pests of R.L. Metcalf) is described in Figure 2.

IPM appeared on the world scene against this backdrop of a mounting record of failures of insecticides to control arthropod pests that had become resistant, and of other real or potential environmental disasters. The first fundamental premise of IPM, and its most anticipated promise, was that as adoption of new IPM systems expanded, the overwhelming reliance on insecticides to control pests, and consequently the use of insecticides, would proportionally decrease. Thus, success of IPM began to be measured in terms of pesticide reduction. The inverse correlation between IPM adoption and pesticide use was not, however, the explicit goal of IPM. Under certain unique circumstances. IPM may

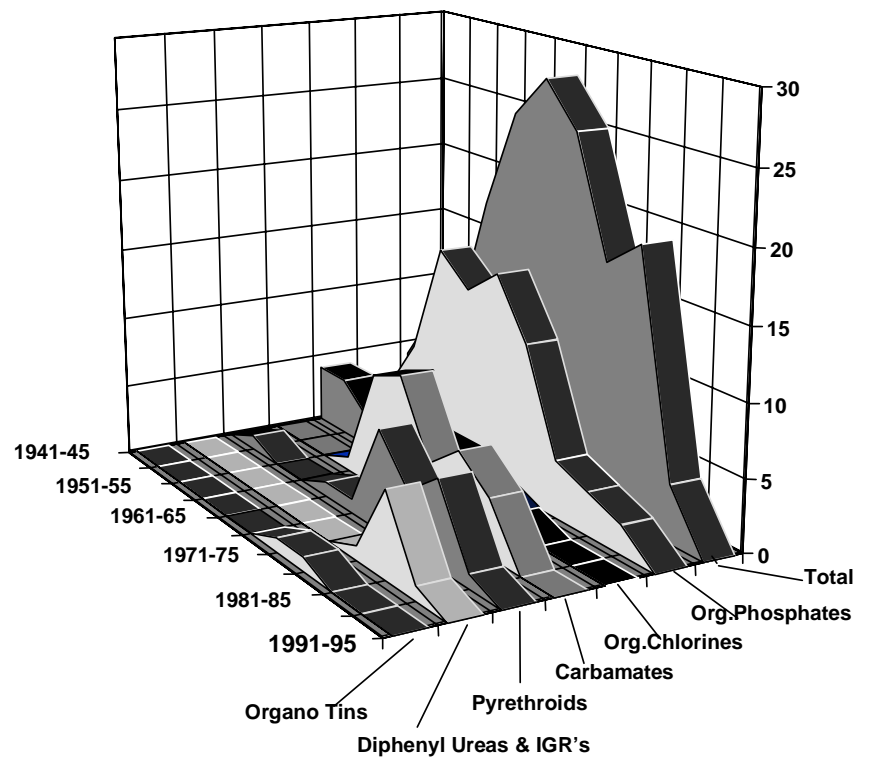

Figure 1. Dates of origin and relative number of compounds in the major classes of chemical insecticides. 


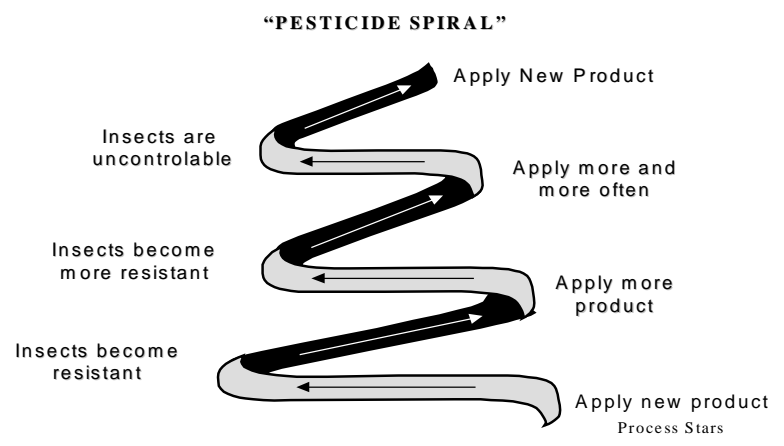

Figure 2. Adaptation of a graphic representation of metaphor of the pesticide treadmill (van den Bosch 1978). An ascending spiral seems to better illustrate the dynamics of this process. (Adapted from Thompson 1998).

lead to an increase in pesticide use because it may reveal pest/crop/socioeconomic interactions that, at least temporarily, are not amenable to the application of control tactics other than insecticides. For instance, cowpea yields in African traditional cropping systems are between 100 and $250 \mathrm{~kg} / \mathrm{ha}$. Yield increases of up to 10 fold are obtained with the application of insecticides (Jackai \& Doust 1986). Given the nutritional value of the crop and the economic conditions of large segments of the population that relies on cowpea as a source of protein, increased pesticide use, until alternatives are found, is justified and compatible with sound IPM principles. The second fundamental premise of IPM was that losses to pests would tend to decline because IPM would lead to greater stability of the biotic crop community. A stable crop community would keep pest population fluctuations under economic injury levels, and risk of uncontrolable outbreaks would be reduced. How IPM has met these promises provides a good indication of its global reality. But be- fore we discuss this issue we need to establish common ground on the concept of IPM and its definition.

\section{Definitions and Concepts}

To assess levels of IPM adoption it is necessary to reach consensus on a definition of IPM. An ongoing search of the literature has yielded 67 definitions, proposed between 1959 (definition of integrated control) and 1998 (see Compendium of IPM Definitions at http://ippc.orst.edu/IPMdefinitions). An analysis of the frequency of key words or expressions included in those definitions is summarized in Table 1.

The concept of decision making implicitly permeates most definitions of IPM. In an attempt to reconcile those multiple definitions as they evolved over the years, the following was recently proposed and serves as the basis for the topic of this paper.

"IPM is a decision support system for the selection and use of pest control tactics, sin- 
Table 1. Frequency of occurrence of terms or expressions used in 67 definitions of IPM compiled in the Compendium of IPM Definitions (Bajwa \& Kogan 1997).

\begin{tabular}{llc}
\hline Term or expression & Referenced context & Frequency (\%) \\
\hline Economics & $\begin{array}{l}\text { Of the benefits to producers or users of the system } \\
\text { Environment }\end{array}$ & 53.8 \\
& $\begin{array}{l}\text { in computation of benefits and costs of the IPM } \\
\text { system beyond the producer level }\end{array}$ & 48.1 \\
Pest populations & $\begin{array}{l}\text { Target for control tactics } \\
\text { Goal of the IPM system }\end{array}$ & 40.4 \\
Pest control & $\begin{array}{l}\text { Components of the control actions } \\
\text { Methods or tactics }\end{array}$ & 38.3 \\
Ecology or ecological & $\begin{array}{l}\text { The conceptual foundation of IPM or } \\
\text { the system impacted by IPM tactics }\end{array}$ & 26.9 \\
System & $\begin{array}{l}\text { Implementable program or ecological unit } \\
\text { Combination or multiple }\end{array}$ & Tactics or control methods \\
Economic threshold/ & Bases for decision making & 24.0 \\
Economic injury level & Bptimization/ & Benefits to producers, society, environment \\
Maximization & Factor in computation of benefits and costs of the & 19.2 \\
Social/ Sociological & IPM system beyond the producer level & 17.3 \\
& & 9.6 \\
\hline
\end{tabular}

gly or harmoniously coordinated into a management strategy, based on cost/benefit analyses that take into account the interests of and impacts on producers, society, and the environment" (Kogan 1998).

\section{Pest Control Program or IPM System}

To measure IPM adoption, it is necessary to identify the factors that determine whether a pest control program qualifies as an IPM system. The measurement of IPM has been the subject of much debate in the U.S.A. owing to the need to assess progress towards achievement of the goals set by the National IPM Initiative of 1996 of $75 \%$ of all crop acres under IPM by the year 2,000 (Day 1998).

As defined above, IPM is essentially a decision making process; consequently, to be IPM a pest control program must provide that: A) control decisions are based on proper cost/ benefit evaluations (the practical expression for these evaluations is the concept of economic injury level and its operational deriva- tive, economic thresholds (Higley \& Pedigo 1996), as well as dynamic models that extend these concepts); B) costs include all direct expenses with pest control actions (cost of product, application costs, cost of scouting, etc.), as well as indirect costs to the environment and to society; and C) benefits include the economic value of the results of the control action (crop loss that was prevented) and the benefits to the environment and to society. In addition, there must be evidence that the system attempts to employ the fundamental methodologies that are part of the IPM repertoire. Those methodologies are summarized in the next section.

Indicators of an IPM System: Criteria used to evaluate an IPM system include some of the following.

A) Use of appropriate sampling or monitoring procedures Pests and natural enemy population levels are sampled to support decisions based on economic injury levels and for ini- 
tialization of simulation models. The activity includes one or more of the following:

-Monitoring pest and natural enemy population trends;

-Pest phenology in relationship to crop phenology;

-Incidence of entomopathogens;

-Incidence of plant diseases;

-Assessment of weed infestation;

-Surveying crop community biodiversity, including actual and potential pests and their natural enemies;

-Developing historical records of pest incidence and severity.

B) Access to appropriate information to support control decisions The essential information for decision making in IPM includes:

-Established economic injury levels and economic thresholds for all major pests;

-Information on the principal natural enemies and their role in regulating pest populations (needed to apply the concept of inaction thresholds according to Sterling 1984);

-Weed incidence maps and history of patchiness and intensity of weed infestations;

-History of disease incidence;

-Predictive models for arthropod pest dynamics and phenologies, plant disease epiphytotic models;

- Real time weather information to be used in connection with predictive models.

C) Selection of control tactics based on IPM principles In the development of an IPM strategy, control tactics are integrated in a manner that optimizes their benefits avoiding, as possible, incompatibilities among the tactics. Therefore, depending on their availability and reliability, the main control tactics in an IPM program are prioritized in an order that takes into account their relative environmental impact, compatibility with other tactics, and cost effectiveness. That order for arthropod pest management is:

- Planting of resistant cultivars;

- Cultural controls, including habitat management to enhance natural enemy activity;

-Classical biological control (self-perpetuat- ing) where applicable for invading pests of foreign origin;

-Augmentative biological control (mass releases) aimed at native pests that have escaped naturally occurring controls;

- Biorrational pesticides, including botanicals, natural products (kairomones or allomones), pheromones as well as microbials (Copping 1998, Hall \& Menn 1999).

- Selective pesticides; chemical pesticides whose mode of action restrict their activity to well defined taxonomic groups of pests thus reducing risk to non-target species (Croft 1990);

-Broad spectrum pesticides (as a last resort).

D) Consideration of environmental impacts of control actions The following are some of the environmental impacts that should be assessed in the selection of a control tactic consider for inclusion in an IPM strategy:

-Impact on naturally occurring beneficial arthropods, including natural enemies of the main pests; alternative hosts for these natural enemies, or any species that plays a role in community dynamics, beyond those previously specified before;

-Effect on wild animals (including birds, terrestrial vertebrates, and aquatic vertebrates), and native plants;

-Impact on soil health, including soil fauna; - Contamination of ground and surface water; -Additional pressure on the evolution of resistance in arthropod, plant pathogen, and weed populations;

-Pressure leading to weed replacement or shift through continued use of certain herbicides (Cousens \& Mortimer 1995).

E) Consideration of the total ecosystem. Understanding ecosystems level interactions is essential for the development of advanced (integration levels II and III) IPM systems. Some of these interactions involve the relationship of the main crop or mix of crops within the context of the regional natural vegetation and successional dynamics (Kogan \& Lattin 1999). Interactions among crops within an agroecosystem, disturbance of natural nutri- 
ent cycles that are managed to maximize production and interference with floral and faunal composition through pest management actions are equally critical to understand, model, and include in development of an advanced IPM strategies.

\section{Performance Criteria for the Effective- ness of an IPM System}

In addition to establishing clear indicators that a pest control program is indeed an IPM system, it is also necessary to provide criteria to measure performance of the system. These criteria relate to the impact of the IPM system on the target pest or pests, effect on crop yield and quality, economic feasibility, and social and environmental impacts. The following is a sample of the many criteria that have been used.

A) Ability of the system to maintain pest populations below established economic injury levels. As the stated goal of an IPM system is to eliminate or at least attenuate the economic impact of pests, efficacy in the reduction of pest populations is a primary indicator of effectiveness of the system.

B) Measurable reduction of pest impact on crop yield and quality over a period of time leading to greater stability in the productivity of the system.

C) Reduction in amounts of production and protection inputs of non-renewable resource origin (mainly pesticides) while maintaining stable productivity levels for the region.

D) Level of adoption of the IPM system by producers.

E) Preservation of environmental quality, as determined by measurable indicators.

F) Increase in safety and comfort of rural workers and their families.

$\mathrm{G})$ Increase in the level of consumer confidence in the safety of agricultural products.

\section{IPM Around the World}

Nearly 30 years after introduction of IPM, pest control is still largely dependent on the use of pesticides. In many countries - de- veloping countries in particular — pesticide consumption actually increased in the 1990's. For instance, pesticide use has increased by a factor of 39 between 1950 and 1992 and the developing countries now account for one quarter of the world's pesticide use (FAO Statistics). However, the industrial countries of North America and Western Europe still account for over one half of the world's pesticide sales (Table 2). Pesticide use as measured in tons of active ingredient seems to have leveled off in the U.S.A. in the decade of the 1990's (Figure 3B). Use has generally declined in The Netherlands, Denmark, and Sweden, and slightly increased in the U.K. By contrast, a sharp increase was recorded in Brazil (Figure 3A). These are all countries with strong IPM programs, based on excellent research and outreach efforts.

Problems with pesticide-intensive pest control programs (see above) are the driving force behind IPM adoption or at least consideration for its adoption at the national or local level in most countries, and in many it has become official governmental policy. A worldwid survey ( 75 countries) by the United Nation Food and Agriculture Organization (FAO 1993) revealed steady progress in development and promotion of IPM in all regions of the world. All countries acknowledged IPM as a desirable approach to pest control even if it was not widely adopted. The percentage of those reporting that IPM was still "at an early stage of development" was reduced from 50 to 45 in developing countries and from 9 to 0 in developed countries in 1987 and 1993, respectively.

IPM is an information-intensive, site-specific, multitactic approach to pest control. Rates and levels of adoption of IPM are determined by the resultant interplay of a regional producers culture and experience, influenced by promotional efforts of the agrochemical industry, moderated by public educational and outreach efforts and availability of extension support. In contrast to the rapid adoption of pesticide technology worldwide, adoption of a newly developed IPM approach or technology may take years. Ta- 
Table 2. World sales of agrochemicals in the major regions of the world.

\begin{tabular}{|c|c|c|c|c|c|c|}
\hline \multirow[b]{3}{*}{ Region } & \multicolumn{6}{|c|}{ World sales of agrochemicals per region } \\
\hline & \multicolumn{2}{|c|}{$1990^{1}$} & \multicolumn{2}{|c|}{$1992^{2}$} & \multicolumn{2}{|c|}{$1996^{3}$} \\
\hline & $\begin{array}{c}\text { US \$ } \\
\text { (billion) }\end{array}$ & $\begin{array}{c}\% \\
\text { share }\end{array}$ & $\begin{array}{c}\text { US \$ } \\
\text { (billion) }\end{array}$ & $\begin{array}{c}\% \\
\text { share }\end{array}$ & $\begin{array}{c}\text { US \$ } \\
\text { (billion) }\end{array}$ & $\begin{array}{c}\% \\
\text { share }\end{array}$ \\
\hline North America & 5.4 & 21.9 & 7.3 & 29.2 & 9.2 & 29.4 \\
\hline Western Europe & 6.6 & 26.7 & 6.7 & 26.7 & 8.2 & 26.2 \\
\hline Eastern Europe & 1.9 & 7.7 & 1.2 & 4.6 & na & na \\
\hline Asia & 6.8 & 27.5 & 6.1 & 24.4 & 7.7 & 24.5 \\
\hline Africa & 1.2 & 4.9 & na & na & na & na \\
\hline Latin America & 2.8 & 11.3 & 2.4 & 9.5 & 3.3 & 10.4 \\
\hline Rest of the World & na & na & 1.4 & 5.6 & 3.0 & 9.5 \\
\hline Total & 24.7 & 100 & 25.0 & 100 & 31.3 & 100 \\
\hline
\end{tabular}

na= not available, 1. GIFAP, 1992. Asia Working Group. Publication of International Group of National Associations of Manufacturers of Agrochemical Products, Brussels. 2. Chemistry \& Industry, 15 November 1993. 3. Agrow: World Crop Protection News, December 13, 1996, February 14 and February 28, 1997.

ble 3 provides a summary of possible reasons for the contrast in the rates of adoption of these crop protection technologies. In addition to the reasons suggested in Table 3 , because of differences in climate, pests, soil, variety and other factors, a well-developed IPM program for a crop in a particular location may not necessarily work well in another situation. Farmers need site-specific information. Generally, they have to work with local IPM information providers (research and extension specialists, NGO's, private consultants) to acquire the information and knowledge necessary for developing an IPM program suited to their needs. Thus, IPM is a diffuse technology not amenable to generalized prescriptions. Decisions must be made at the local, or at best, at the regional level.

Adoption of IPM can be viewed under a continuum, starting with systems largely confined to using a single tactical approach such as using economic thresholds for better timing of pesticide applications. Along the continuum, additional non-chemical tactics such as cultural controls, biological controls, re- sistant crop varieties, mating disruption, sterile insect release, etc., may be integrated into the system. Above a certain level of tactical integration, a threshold is reached at which a previously, pesticide-centered program, becomes an IPM system. At the other extreme of the continuum, higher levels of integration are reached including multiple pest impacts and consideration of ecosystem processes. Eventually a stage is reached at which pesticide use is minimized with a concurrent increase in the amount of time and management skills that are devoted to IPM operations (Figure 4). With its success in many parts of the world, IPM is viewed as an ecologically benign and cost-effective pest control strategy ideally suited for both small and large farmers around the world.

IPM has been adopted as the central paradigm for crop protection by virtually all international agricultural research centers, the FAO, and many governments in both developed and developing countries. Measuring IPM adoption, however, is a complex but much needed process because it provides in- 


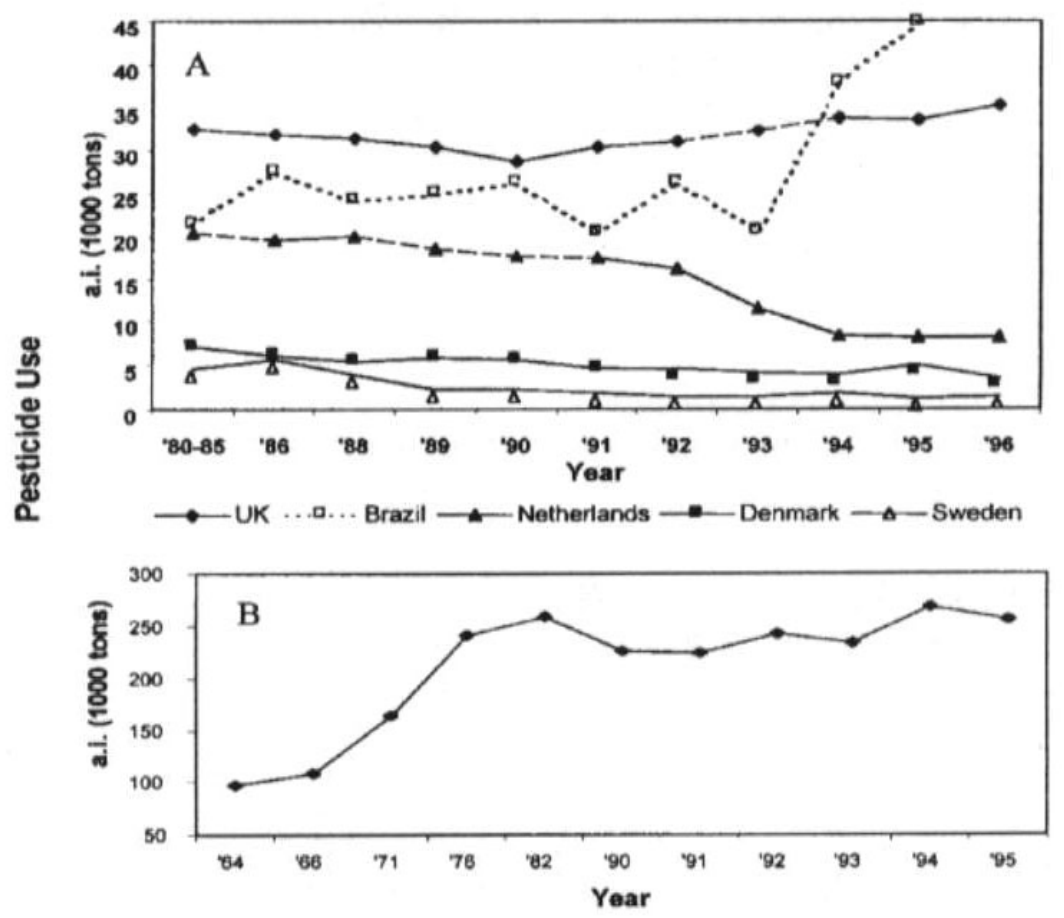

Figure 3. A- Pesticide use in Brazil, the U.K., Denmark, The Netherlands, and Sweden, 1980 - 1996. Source: FAO Statistical Division (1980 - 1996), FAO Yearbook - Production (1980 - 1996) and ANDEF 1991. B- Pesticide use on major crops in the U.S.A., 1964 - 95. Crops: corn, cotton, soybeans, wheat, potatoes, other vegetables, citrus, and apples and other fruits (about 67\% of U.S. cropland). Source: Economic Research Service, USDA (1996 - 97)

formation about the efficiency of an IPM program, identifies constraints to adoption, and identifies areas in need of improvement. Reliable estimates of IPM adoption are not available presently for most crops. In fact, the measurement of IPM adoption depends largely on the definition of IPM (see above). IPM is often viewed as a strategy to integrate two or more control tactics. However, a decision to do nothing perhaps is the most desirable state of an IPM program in which forces of nature are identified as, per se, capable of achieving adequate pest population regulation. Such a stage, what Sterling (1984) called the innaction threshold, requires no integration of tactics, merely a profound understanding of the ecology of the agricultural system. Such was perhaps the nature of the most heralded IPM success in the world, the control of the brown planthopper, Nila parvata lugens, in Southeast Asia (Kenmore 1996).

In most countries, some form of IPM now exists with varying degrees of sophistication and adoption. Major effort has been directed to crops such as banana (Costa Rica), cotton (U.S.A., many Asian, African, and South American countries), rice (many Asian and African countries), soybean (U.S.A. and South American countries), maize (U.S.A., many Asian and African countries), vegetables (most countries), pome fruits (Europe, Australasia, and North America), citrus fruits (U.S.A. and Australia), and plantation crops 
Table 3. Contrasting features of pesticide technology and IPM as possible reasons to explain the fast rate of adoption of the former and the slow of adoption of the latter.

Pesticides

IPM

Compact technology from acquisition to application. Easily incorporated into regular farming operations.

Promoted by the private sector.

Strong economic interests. Large budgets for R\&D.

Aggressive sales promotion supported by professionally developed advertising campaigns.

Skillful use of mass communications media.

Capable of providing incentives to "adoption" (free advise, slick publications, bonuses and small gifts).

Results of applications usually immediately apparent.

\section{Consequently: Pesticide technology was rapidly adopted.}

Diffuse technology with multiple components. At times difficult to reconcile with normal farming operations.

Promoted by the public sector.

Budgets extremely limited for R\&D.

Promoted by Extension personnel usually trained as educators not as salespersons.

Limited support of trained communications media personnel. Educational programs of restricted scope.

Technical support usually provided, but limited by inadequate staffing. No material incentives.

Benefits often not apparent in the short run. Some difficult to demonstrate (e.g., results of biological control).

\section{Consequently: Adoption of IPM} technology has been slow.
(Malaysia) (Tables 4-8). Several regional IPM programs have successfully been implemented on crops such as cassava (mealy bug in Africa), coconut (rhinoceros beetle in Asia/ Pacific), crucifers (diamondback moth in Asia), and rice (brown planthopper in tropical Asia) (Mengech et al. 1995, Soon 1996). Experience from these examples has shown that IPM can work very well in both developed and developing countries; however, successful implementation requires raising general awareness of IPM and training at the research, extension, and farm levels. In many developing countries, IPM was found economically more efficient than conventional pest control approaches based on intensive use of pesticides. In these countries, a 50-100\% reduction in pesticide use is possible with no detrimental effects on yield (Soon 1996).
In 1994 the U.S. Department of Agriculture estimated IPM adoption for field crops, fruits, nuts, and vegetables. These estimates were based on data gathered through chemical use/cropping practices surveys carried out from 1990 -1993 (Vandeman et al. 1994). The surveys covered selected states accounting for most of the U.S. area in these crops. The estimates are given in Table 4. It was found that $5-15 \%$ of the area was under low level (just scouting \& use of economic thresholds (ET) or at the level we call the IPM threshold), 23 - 35\% under medium level (scouting, ET and one or two additional practices) and 20 - 30\% under a high level (scouting, threshold and three or more additional practices) of IPM. Overall, $50 \%$ or more of the crop acreage in fruits, nuts, vegetables, and field crops was under IPM for at least one of the three 


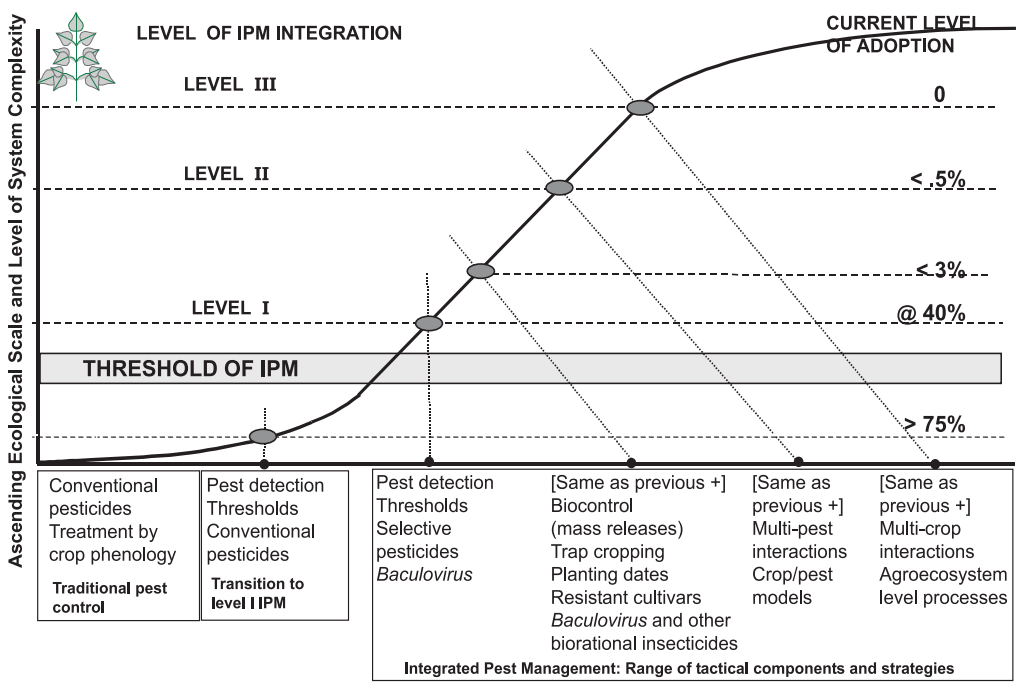

Figure 4. Continuum from conventional pest control to level III IPM, as exemplified by soybean IPM in Brazil. A minimum set of tactical components determines the "threshold of IPM".

major pest types: insects, diseases, and weeds. IPM was found to be more prevalent on grapes (54\% of reported acres), oranges $(64 \%)$, and almonds (54\%). Pesticides were applied without economic thresholds (a non-IPM practice) on $60-90 \%$ of berry, cherry, and peach acres. Among fruit and nut crops where advanced IPM programs were well tested, adoption was higher, e.g., apples (27\%), grapes (37\%), oranges $(26 \%)$, and almonds (32\%). In vegetables, $52 \%$ of the area was under IPM with more than half classified as high-level IPM. Among field crops, $74 \%$ and $72 \%$ of planted area was under IPM for corn and fall potatoes, respectively. About $38 \%$ of the fall potato acres was classified at high level IPM for insects. Lack of crop consultants to deliver IPM services and the higher managerial input necessary for IPM implementation were the most frequent impediments to adoption. Ac- cording to Warner (1998), 100\% of fruit growers in Washington state (U.S.A.) are using IPM to some degree.

In western Europe, $35 \%$ of the total area $(322,000 \mathrm{ha})$ of pome fruit production is under Integrated Fruit Production (IFP), an approach in which IPM has a central role. The area has increased by $40 \%$ since 1991 (Schafermeyer, 1991). Area under pome IPM in western Europe is given in Table 5. Adoption of IFP over a large area has lead to promotion of higher standards of integrated pest management, up to $30 \%$ reduction in pesticide use, and use of environmentally benign pesticides (Cross et al. 1995). IFP has received a warm welcome from developed countries in other parts of the world, e.g., U.S.A. [Massachusetts (Hollingsworth 1996), Oregon (Riedl personal communication), Washington (Reed \& Nelson 1996)], and New 
Table 4. IPM adoption in field, vegetable, fruit and nut crops in major producing states of USA,1991-94.

\begin{tabular}{|c|c|c|c|c|c|c|}
\hline \multirow[b]{2}{*}{ Crop } & \multicolumn{3}{|c|}{ Production area } & \multicolumn{3}{|c|}{ Planted hectares under IPM (\%) } \\
\hline & \multicolumn{3}{|c|}{$\begin{array}{ccc}\text { Total US } & \text { Producing states } \\
(1,000 \mathrm{Ha}) & \begin{array}{c}\text { reporting } \\
(1,000 \mathrm{Ha})\end{array} & \text { Hectares } \\
& \end{array}$} & Insects & Diseases & Weeds \\
\hline \multicolumn{7}{|l|}{ Field Crops } \\
\hline Corn & 29,537 & 26,583 & 90 & $74(22)$ & na & $53(51)$ \\
\hline Cotton & 5,484 & 1,584 & 29 & 71 & na & na \\
\hline Soybean & 25,760 & 21,638 & 84 & na & na & $59(57)$ \\
\hline Fall Potatoes & 482 & 453 & 94 & $72(69)$ & $63(58)$ & $66(65)$ \\
\hline Vegetables & & & & $52(43)$ & $41(29)$ & $35(33)$ \\
\hline Lettuce & 108 & 105 & 97 & $81(59)$ & $80(42)$ & $41(41)$ \\
\hline Melons & 165 & 132 & 80 & $56(48)$ & $52(34)$ & $47(47)$ \\
\hline Sweet corn & 305 & 259 & 85 & $43(34)$ & $34(25)$ & $46(46)$ \\
\hline \multirow[t]{3}{*}{ Tomatoes } & 166 & 144 & 87 & $66(55)$ & $41(36)$ & (23) 23 \\
\hline & & & & \multicolumn{3}{|c|}{ All pests (insect, weed, disease) } \\
\hline & & & & \multicolumn{2}{|c|}{ High IPM } & \multirow{2}{*}{$\begin{array}{c}\text { Total } \\
50(44)\end{array}$} \\
\hline \multicolumn{4}{|l|}{ Fruits \& nuts } & \multicolumn{2}{|c|}{31} & \\
\hline Almond & 156 & 154 & 99 & \multicolumn{2}{|c|}{32} & $54(53)$ \\
\hline Apple & 188 & 154 & 82 & \multicolumn{2}{|c|}{27} & $42(41)$ \\
\hline Grapes & 299 & 296 & 99 & \multicolumn{2}{|c|}{37} & $54(48)$ \\
\hline Oranges & 248 & 248 & 100 & \multicolumn{2}{|c|}{26} & $64(49)$ \\
\hline Pear & 29 & 28 & 95 & \multicolumn{2}{|c|}{26} & $40(37)$ \\
\hline Walnuts & 74 & 74 & 100 & \multicolumn{2}{|c|}{31} & $43(41)$ \\
\hline
\end{tabular}

Values in parenthesis are based on the IPM threshold concept by Kogan, 1998. na = not available. Source: Cotton - Fernandez 1994 (Reporting States: Alabama, Arkansas, California, Georgia and N. Carolina); All other Crops - Vandeman et al. 1994. 54 (53)

Zealand and Australia (Cross et al.1995). Implementation of IFP is not confined to western Europe or the developed world, it is spreading to many other fruit growing countries, e.g., Poland (Zurawicz et al. 1996), Hungary (Balázs et al. 1996), South Africa, and Argentina (Cross et al. 1995) have recently started initiatives to adopt IFP methods.

In the developed world (both in Europe and North America), the food industry (particularly baby food products) has recently accepted the concept of IPM and is actively encouraging its development and adoption. In the last few years, food processors have helped disseminate IPM information to their contract growers. Several companies have hired IPM specialists to conduct IPM research and development programs for their growers. Some companies help promote IPM by purchasing products from IPM/IFP/Organic growers (Sorensen 1998, Esbjerg personal communication).

In many developing countries, where IPM is now governmental policy, pesticide usage is being reduced. In these countries, regular use of pesticides is limited to high value (cash) crops and, as such, IPM adoption is largely centered on cotton, rice, soybean, and sugarcane. Pest monitoring and warning pro- 
grams have been established at the national and local levels in several countries like China, India, Indonesia, Malaysia, Korea, Pakistan, Philippines, and Thailand in Asia (Raheja 1995). Estimates on IPM adoption in some crops are given in the Tables 5-7. These tables contain information on direct measurement such as area under IPM or indirect measurement such as impact on reduction in pesticide use, application frequency, or treated area.

In Asia, various stages of IPM have been successfully adopted in Bangladesh (rice), China (cotton, fruit crops, maize, rice, soybean, vegetables), India (cotton, fruit crops, sugarcane, vegetables), Indonesia (rice), Korea (rice), Malaysia (vegetables, plantation crops), Pakistan (cotton, mango, sugarcane), Philippine (rice), Tadjikistan (cotton), Thailand (cotton), Turkmenistan (cotton), Vietnam (rice) (Tables $6 \&$ 8, Ooi et al.1991, Raheja 1995, Morse \& Buhler 1997). In irrigated rice (Table 6), IPM is being practiced on about 6.6 million hectares out of a total of 133 million ha in Asia. Information on IPM adoption is generally not available for many countries where emphasis was given to biological means of pest control as the major component of IPM. In these countries mass production and release of several biocontrol agents have occurred without subsequent study of the effect of the program. In China, where large-scale mass release of biocontrol agents has been adopted for many years, it was estimated that by the end of 1991, the area covered under the mass release program was 25.8 million hectares and 2.2 million hectares were under microbial control (Liu \& Piao, 1992).

In Southeast Asia, a major breakthrough in IPM occurred in Indonesia in 1986-87 when IPM was adopted as the national crop protection strategy. Fifty seven of 66 broad spectrum pesticides used on rice at the time were banned by presidential decree (Morse \& Buhler 1997). This decree endorsed IPM as

Table 5. IPM adoption in Europe.

\begin{tabular}{|c|c|c|c|c|c|c|}
\hline \multirow{2}{*}{$\begin{array}{l}\text { Country/ } \\
\text { Region }\end{array}$} & \multirow[b]{2}{*}{ Crop } & \multicolumn{2}{|c|}{ Area (1000 ha) } & \multirow{2}{*}{$\begin{array}{c}\text { Area } \\
\text { under } \\
\text { IPM } \\
(\%)\end{array}$} & \multirow{2}{*}{$\begin{array}{l}\text { Farmers } \\
\text { adopted } \\
\text { IPM (\%) }\end{array}$} & \multirow{2}{*}{ Reference } \\
\hline & & $\begin{array}{l}\text { Total } \\
\text { Crop }\end{array}$ & $\begin{array}{c}\text { IPM } \\
\mathrm{Ha} \\
\end{array}$ & & & \\
\hline Western Europe & Apple \& pear & $r \quad-$ & - & 50 & - & Reed 1995 \\
\hline Western Europe & Pome fruits & 920 & 322 & 35 (1994) & - & Cross et al. $1995^{*}$ \\
\hline Western Europe & Fruit crops & - & - & 29 & - & Reed 1993 \\
\hline Austria & Pome fruits & 5.83 & 4.77 & 82 & 51 & Cross et al. 1995* \\
\hline Belgium & Pear & - & - & - & $98 \%$ & Schaetzen 1996 \\
\hline Belgium & Pome fruits & 20.00 & 4.51 & 23 & 31 & Cross et al. $1995^{*}$ \\
\hline Denmark & Pome fruits & 3.44 & 0.96 & 28 & 17 & Ibid \\
\hline France & Pome fruits & 75.00 & 0.50 & $<1$ & $\sim 1$ & Ibid \\
\hline Germany & Pome fruits & 38.60 & 30.44 & 79 & 27 & Ibid \\
\hline UK & Pome fruits & 17.00 & 13.00 & 76 & 77 & Ibid \\
\hline Italy & Pome fruits & 71.24 & 38.00 & 53 & 47 & Ibid \\
\hline Netherlands & Pome fruits & 21.00 & 14.80 & 70 & 57 & Ibid \\
\hline Portugal & Pome fruits & 25.50 & 1.10 & $\sim 4$ & $<1$ & Ibid \\
\hline Spain & Pome fruits & 56.00 & 0.40 & $<1$ & $<1$ & Ibid \\
\hline Switzerland & Pome fruits & 6.08 & 4.35 & 72 & 39 & Ibid \\
\hline
\end{tabular}

*Values represent adoption of Integrated Fruit Production (IFP). 
the official "strategy" for rice production. Subsidies on pesticides were reduced from $75 \%$ in 1986 to $40 \%$ in 1987 and removed altogether by January 1989 (APO 1993). Five years later, rice yields increased by 15 percent, while pesticide use dropped by 60 per- cent (Morse \& Buhler 1997). In the first two years alone the government saved US\$120 million that it would have spent subsidizing chemicals (Wardhani 1991, WRI 1994). The overall economic impact of IPM has been estimated at US \$1 billion (WRI 1994). This

Table 6. IPM adoption and/or its impacts in Africa, Asia and Australasia.

\begin{tabular}{|c|c|c|c|c|c|c|c|}
\hline \multirow{3}{*}{$\begin{array}{l}\text { Country/ } \\
\text { region }\end{array}$} & \multirow{3}{*}{ Crop } & \multicolumn{2}{|c|}{$\begin{array}{c}\text { Area } \\
(1000 \mathrm{ha})\end{array}$} & \multirow{3}{*}{$\begin{array}{c}\text { Area } \\
\text { under } \\
\text { IPM }\end{array}$} & \multirow{3}{*}{$\begin{array}{c}\text { Farmers } \\
\text { adopted } \\
\text { IPM } \\
(\%) \\
\end{array}$} & \multirow{3}{*}{$\begin{array}{c}\text { Reduction in } \\
\text { pesticide use } \\
\mathrm{Af}^{\mathrm{b}} \text { or } \mathrm{TA}^{\mathrm{c}} / \mathrm{CC}^{\mathrm{d}} \\
\end{array}$} & \multirow[t]{3}{*}{ Reference } \\
\hline & & \multirow{2}{*}{$\begin{array}{l}\text { Total } \\
\text { crop }\end{array}$} & \multirow[t]{2}{*}{ IPM } & & & & \\
\hline & & & & & & & \\
\hline \multirow[t]{3}{*}{ Asia } & \multirow[t]{3}{*}{ Rice } & 132,158 & - & - & - & $35-100^{b}$ & FAO 1994 \\
\hline & & 132,100 & 4,900 & 3.71 & - & $28^{\mathrm{a}}(5 \mathrm{Y})$ & Raheja 1995 \\
\hline & & 133,000 & 6,600 & 4.96 & - & - & $\begin{array}{l}\text { Morse \& Buhler } \\
1997\end{array}$ \\
\hline \multirow{9}{*}{$\begin{array}{l}\text { Australia } \\
\text { Bangla- } \\
\text { desh } \\
\text { China }\end{array}$} & Cotton & 270 & - & - & 90 & - & Fitt 1994 \\
\hline & Rice & 9,919 & - & - & - & $95^{\mathrm{c}}(14 \mathrm{Y})$ & Raheja 1995 \\
\hline & Cotton & 5,200 & 15,00 & $\begin{array}{c}29 \\
(1990)\end{array}$ & - & - & Zhaohui et al. 1992 \\
\hline & Cotton & - & - & - & - & $85^{\mathrm{b}}(10 \mathrm{Y})$ & Raheja 1995 \\
\hline & Maize & 20,350 & 2,000 & 10 & - & - & Zhaohui et al. 1992 \\
\hline & Rice & 32,500 & 10,000 & $\begin{array}{c}31 \\
(1990)\end{array}$ & - & - & Ibid \\
\hline & Soybean & 8,000 & 1,500 & $\begin{array}{c}19 \\
(1990)\end{array}$ & - & - & Ibid \\
\hline & \multicolumn{2}{|c|}{ Vegetables $^{1}$ - } & - & - & - & $\mathrm{d}$ & Raheja 1995 \\
\hline & Wheat & 29,850 & 6,000 & $\begin{array}{c}20 \\
(1990)\end{array}$ & - & - & Zhaohui et al. 1992 \\
\hline India & Cotton ${ }^{2}$ & - & - & - & - & $70^{\mathrm{b}}(15 \mathrm{Y})$ & Raheja 1995 \\
\hline Indonesia & a Rice & 10,734 & - & - & - & $60^{a}$ & $\begin{array}{l}\text { Morse \& Buhler } \\
1997\end{array}$ \\
\hline & & & & & & (1994) & \\
\hline Pakistan & Mango $^{3}$ & 13 & 3.3 & 25 & - & - & Soon 1996 \\
\hline Sudan & Cotton & - & - & - & - & $50^{a}$ & $\begin{array}{l}\text { Pretty 1995, Morse } \\
\text { \& Buhler } 1997\end{array}$ \\
\hline Tajikistan & Cotton & 300 & - & - & - & $\sim 85^{\mathrm{a}}(22 \mathrm{Y})$ & Sugonyaev 1994 \\
\hline $\begin{array}{l}\text { Turkmen- } \\
\text { istan }\end{array}$ & Cotton & 620 & - & - & - & $\sim 99^{\mathrm{a}, \mathrm{c}}(24 \mathrm{Y})$ & Ibid \\
\hline
\end{tabular}

a: Pesticide Use; b :Application Frequency; c: Treated Area; d: Pest Control Cost; Y: Year (s); M: Million; Reporting Area: The whole country except for 1: 200 cities in 22 provinces of China; 2: State of Andhra Pradesh, India ; 3: Province of Punjab, Pakistan. 
is one of the best examples of successful IPM in the world (Kenmore 1996, Morse \& Buhler 1997). Part of this success came from field schools which allowed local farmers to harness their indigenous knowledge of natural pest control to IPM (Morse \& Buhler 1997).

Table 7. IPM adoption and/or its impact in the Americas (countries other than USA).

\begin{tabular}{|c|c|c|c|c|c|c|}
\hline \multirow{3}{*}{ Country } & \multirow{3}{*}{ Crop } & \multicolumn{2}{|c|}{$\begin{array}{c}\text { Area } \\
(1000 \text { ha })\end{array}$} & \multirow{2}{*}{$\begin{array}{c}\text { Farmers } \\
\text { adopted } \\
\text { IPM } \\
\end{array}$} & \multirow{2}{*}{$\begin{array}{l}\text { Reduction in: } \\
\text { pesticide use } \\
\mathrm{AF}^{\mathrm{b}} \text { or } \mathrm{TA}^{\mathrm{c}} / \mathrm{CC}^{\mathrm{d}}\end{array}$} & \multirow[t]{3}{*}{ Reference } \\
\hline & & \multirow{2}{*}{$\begin{array}{l}\text { Total } \\
\text { crop } \\
\end{array}$} & \multirow[b]{2}{*}{ IPM } & & & \\
\hline & & & & \multicolumn{2}{|c|}{$(\%)$} & \\
\hline Argentina & Soybean & 5,935 & - & - & $50^{\mathrm{b}}$ & Aragon 1991 \\
\hline Canada & $\begin{array}{l}\text { Field crops, } \\
\text { fruits \& } \\
\text { Vegetables }^{1}\end{array}$ & - & - & - & $30-50^{a}$ & $\begin{array}{l}\text { Surgeoner \& } \\
\text { Roberts } 1993\end{array}$ \\
\hline \multirow[t]{8}{*}{ Brazil } & Cassava & - & $34^{2}$ & 50 & $80-90^{d}$ & Braun, et al. 1993 \\
\hline & Citrus & $1,000^{3}$ & - & - & $\begin{array}{c}77^{\mathrm{b}} \\
\text { (1970 vs. 95) }\end{array}$ & $\begin{array}{l}\text { Campanhola et al. } \\
1995\end{array}$ \\
\hline & Cotton & $222^{4}$ & - & 70 & - & Ramalho 1994 \\
\hline & Soybean & 5,935 & - & - & $85^{\mathrm{b}}(11 \mathrm{Y})$ & $\begin{array}{l}\text { Campanhola et al. } \\
1995\end{array}$ \\
\hline & & 11,100 & - & $\begin{array}{c}40 \\
(1991)\end{array}$ & $60-80^{\mathrm{b}}(25 \mathrm{Y})$ & $\begin{array}{l}\text { Ibid, Iles \& } \\
\text { Sweetmore, } 1991\end{array}$ \\
\hline & & 10,728 & - & 40 & $60^{\mathrm{a}}$ & $\begin{array}{l}\text { Moscardi \& } \\
\text { Sosa-Gomez } 1996\end{array}$ \\
\hline & Sugarcane & 4,183 & 150 & - & - & $\begin{array}{l}\text { Campanhola et al. } \\
1995\end{array}$ \\
\hline & Wheat $^{5}$ & - & - & - & $94^{\mathrm{c}}(5 \mathrm{Y}, 1982)$ & Ibid \\
\hline Chile & Wheat & - & - & - & $\begin{array}{l}\text { (Annual saving } \\
\text { US\$ } 20 \mathrm{M})^{\mathrm{a}}\end{array}$ & Ibid \\
\hline \multirow[t]{5}{*}{ Colombia } & Cotton & $26^{6}$ & 26 & - & $85-90^{\mathrm{b}}(1995)$ & Ibid \\
\hline & Cotton & - & $6^{7}$ & - & $97^{\mathrm{b}}(7 \mathrm{Y})$ & Ibid \\
\hline & Sugarcane & $318^{8}$ & 318 & 100 & - & Ibid, Escobar 1986 \\
\hline & Soybean & - & & - & $80-90^{d}$ & Garcia, 1990 \\
\hline & Tomato $^{9}$ & - & - & 70 & $100^{\mathrm{b}}$ & $\begin{array}{l}\text { Campanhola et al. } \\
1995\end{array}$ \\
\hline Costa Rica & Banana ${ }^{10}$ & - & - & - & $100^{a}(1973)$ & Soon 1996 \\
\hline \multirow[t]{2}{*}{ Paraguay } & Cotton & 454 & - & - & $\sim 80^{\mathrm{a}}$ & $\begin{array}{l}\text { Servian de Cardozo } \\
1990\end{array}$ \\
\hline & & $19^{11}$ & - & - & $50^{\mathrm{b}}$ & Ibid \\
\hline Venezuela & Sugarcane & 111 & 50 & - & - & $\begin{array}{l}\text { Campanhola et al. } \\
1995\end{array}$ \\
\hline
\end{tabular}

a : Pesticide Use; b: Application Frequency; c: Treated Area; d: Pest Control Cost; Y: Year (s); M: Million; Reporting Area: The whole country except for 1: Province of Ontario, Canada; 2: State of Paraná, Brazil; 3 \& 4: Sate of São Paulo, Brazil; 5: Wheat-growing areas of Rio Grande do Sul, Paraná and Santa Catarina, Brazil; 6, 8 \& 9: Valle del Cauca, Colombia; 7: Municipality of Zarzal, Colombia; 10: Reduction in insecticide sprays; 11: By Cooperative Colonia Unidas, Paraguay. 
The schools were set up with the assistance of the FAO. In these schools, more than 250,000 farmers received IPM training from 1989 to 1994 (WRI 1994). This success story has proved instrumental for IPM adoption by rice farmers in other Asian countries. Indeed, such a mass scale IPM adoption has influenced and motivated farmers all across the globe. The technology has potential for Africa, which has largely bypassed the green revolution and did not develop the extensive agricultural extension systems found in Asia (Morse \& Buhler 1997). According to Wardhani (1991), Indonesian Rice IPM program represents a social movement. It links the scientific development of ecological concepts with intensive field training of farmers on ecologically sound field management techniques. It represents one of the first largescale examples of a technology which is compatible with environmental conservation, public health, and farmer profitability.

In South America, IPM has been successfully implemented in Argentina (alfalfa, citrus, soybean), Brazil (citrus, cotton, livestock, soybean, sugarcane, tomato, wheat), Chile (wheat), Columbia (cotton, ornamentals, soybean, sugarcane, tomato), Paraguay (cotton, soybean), Peru (cotton, sugarcane), and Venezuela (cotton, sugarcane) (Table 7, Campanhola et al.1995, Soon 1996)

IPM had a promising start in Africa in the late 1970s. In Sudan, IPM produced good results with more than 50 percent reduction in insecticide use (Pretty 1995, Morse \& Buhler 1997). Introduction of a parasitoid wasp, Epidinocarsis lopezi, spectacularly controlled the cassava mealybug, Phenacoccus manihoti, across the cassava belt (Zethner 1995, Soon 1996). This program started in 1979 and by 1990 E. lopezi had become established in 25 countries where cassava is cultivated (Zethner 1995). Although credit for the initial success of the program goes exclusively to the application of principles of classical biological control, preservation of the natural enemies after introduction, and integration with other tactics must be credited to IPM. IPM has been successfully used in South Africa on apple, Togo,

Table 8. Other examples of reported IPM Adoption.

\begin{tabular}{|c|c|c|c|}
\hline Country (ies) & Crop & $\begin{array}{l}\text { Impact - Reduction } \\
\text { in:/Comments }\end{array}$ & Reference \\
\hline Argentina & Citrus & $\begin{array}{l}\text { Pesticide use \& application } \\
\text { frequency }\end{array}$ & Campanhola et al. 1995 \\
\hline $\begin{array}{l}\text { Bangladesh, Burkina } \\
\text { Faso, India \& Sri Lanka }\end{array}$ & Rice & Successfully implemented & Pretty 1995 \\
\hline $\begin{array}{l}\text { Egypt, Sudan, Togo, } \\
\text { Zimbabwe }\end{array}$ & Cotton & Successfully used & Pretty 1995 \\
\hline Malaysia & $\begin{array}{l}\text { Plantation } \\
\text { Crops } \\
\text { Vegetables }\end{array}$ & $\begin{array}{l}\text { Pesticide use (+ Environ- } \\
\text { mental conservation) } \\
\text { Pesticide use }\end{array}$ & $\begin{array}{l}\text { Raheja } 1995 \\
\text { Ibid }\end{array}$ \\
\hline Peru (Canete Valley) & Cotton & $\begin{array}{l}\text { Pesticide use \& control } \\
\text { cost }(1972)\end{array}$ & $\begin{array}{l}\text { Boza-Barducci 1972, } \\
\text { Soon } 1996\end{array}$ \\
\hline South Africa & Apple & $\begin{array}{l}\text { Pesticide use \& application } \\
\text { frequency }\end{array}$ & Nel et al. 1993 \\
\hline
\end{tabular}


Zimbabwe and Egypt on cotton, and Burkina Faso on rice (Table 8). Ghana has recently launched IPM as the national crop protection strategy, which includes controls on the importing of chemical pesticides (Zethner 1995). Countries like Burkina Faso, Cote d'Ivoire, and Kenya are currently focusing more on capacity building as the initial step towards adopting IPM (Zethner 1995). Table 8 provides a list of other IPM programs mentioned in the literature as successful, but with no indication of levels of adoption.

\section{Concluding Remarks}

Despite recent advances in pest control technologies and IPM developments, world crops in the 1990s still suffer losses to the aggregate impact of pre-and post harvest pests similar to those suffered in the beginning of the century. Table 9 provides estimates of losses that lead us to make this assertion. These losses continue to occur even while pesticide use continued to rise worldwide (see Table 3 and Figure 3).

In the U.S.A., where there is considerable emphasis on IPM, the history of insecticide use on cotton and corn is rather revealing (Figure 5). During the 1960s and 70s over 30 million kg of insecticides were applied to control cotton pests, or rates of 6 to $15 \mathrm{~kg}$ per planted hectare. Total amounts and rates per hectare dropped dramatically in the early 1980s' as IPM programs were promoted. This drop, however, can not be solely ascribed to IPM adoption because many of the more modern pesticides are used at rates up to 80-100 times lower than pesticides of the decades of the $60 \mathrm{~s}$ and $70 \mathrm{~s}$. Corn offered another scenario, as insecticide use was three times lower than in cotton in the 1960s and 70s, despite the fact that the area planted to corn in the U.S.A. was six to seven fold greater than the area planted to cotton. From the 1980s on, however, corn surpassed cotton as the largest consumer of insecticides, mainly due to the increased infestations of rootworms (Diabrotica sp.) in the Midwestern corn belt. In the U.S.A., after a sharp increase from the 1960 s through the early 1980 s, overall pesticide use has stabilized between 240 and 280 thousand tons of active ingredient per year

Table 9 . Estimates of crop losses due to pests (Adapted from Pimentel 1986, and Schwartz \& Klassen 1981).

\begin{tabular}{|c|c|c|c|c|}
\hline & \multicolumn{4}{|c|}{ Percentage of crop losses to pests } \\
\hline & Insects & Diseases & Weeds & Total \\
\hline Without pesticides & 18 & 15 & 9 & 42 \\
\hline 1980 & 13 & 12 & 12 & 37 \\
\hline 1974 & 13 & 12 & 8 & 33 \\
\hline $1951-1960$ & 13 & 12 & 8 & 34 \\
\hline 1942-1951 & 7 & 10 & 14 & 31 \\
\hline 1910-1935 & 10 & NA & NA & NA \\
\hline 1904 & 34 & NA & NA & NA \\
\hline \multicolumn{5}{|c|}{ Summary of global estimates of crop losses due to all pests } \\
\hline \multicolumn{2}{|l|}{ Number of pest species } & \multicolumn{2}{|c|}{10,000} & \\
\hline \multicolumn{2}{|l|}{ Number of key pests } & \multicolumn{2}{|c|}{600} & \\
\hline \multicolumn{2}{|l|}{ Losses in the 1900s' } & \multicolumn{2}{|c|}{$\sim 33 \%$} & \\
\hline \multicolumn{2}{|c|}{ Losses in the 1980s' } & \multicolumn{2}{|c|}{$\sim 33 \%$} & \\
\hline \multicolumn{4}{|c|}{$10-12 \%$ of losses attributed to insects and mites. } & \\
\hline
\end{tabular}




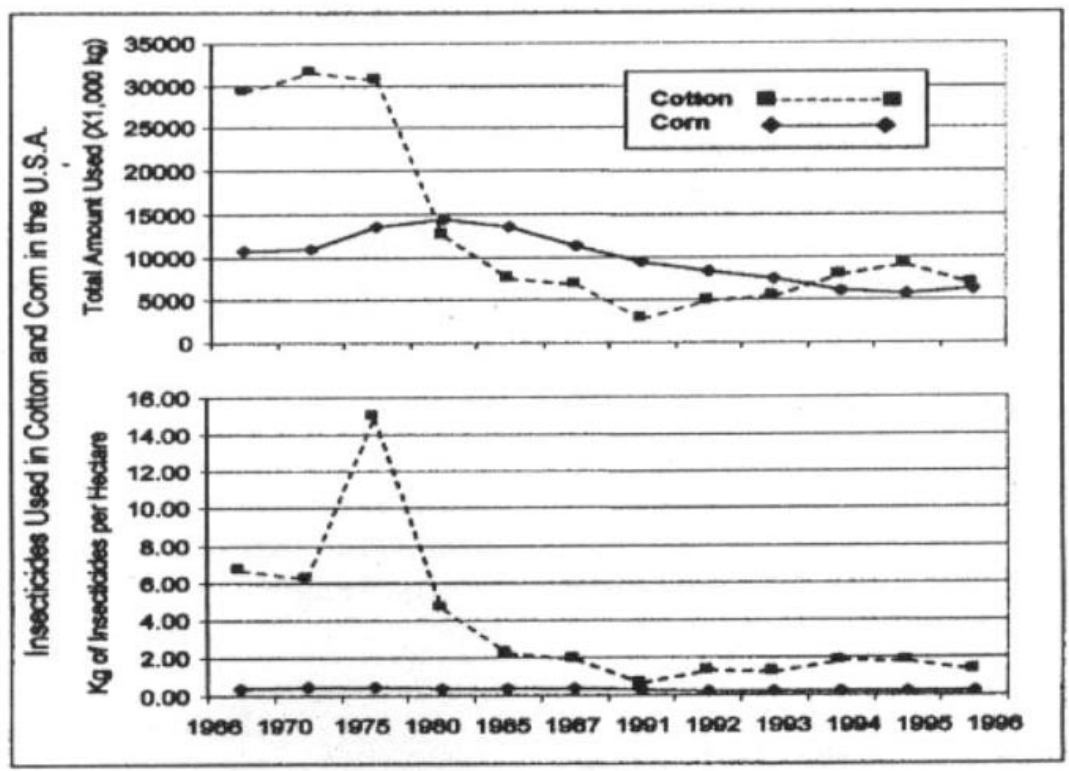

Figure 5. Insecticide used on cotton and corn in the U.S.A., 1966 - 1996. (USDA-ERS)

(see Figure 3B).

Has IPM failed to meet its promise? The answer is definitely not. Even the incomplete picture of IPM adoption around the world, provided by data in Tables 4 through 8 , suggests that IPM has penetrated many regions of the world to which it has brought much needed relief from the burdensome over reliance on pesticides. Intellectually IPM is without a doubt a global reality. Practically, however, IPM is a tangible reality in some privileged regions of the world, but still remains a distant dream for many others. Given the world demographic and social realities, however, adoption of IPM is not an option, it is a vital necessity for the conservation of the environment and for the very survival of the human race on earth.

Andrew Grove, the Intel CEO, calls stra- tegic inflection points "those moments when new circumstances alter the way the world works, as if the current of history goes through a transistor and our oscilloscopes blip." It can happen because of an invention (Gutenberg's printing press in the XVth century), or an idea (individual liberty in the XVIIIth century), or a technology (electricity in the XIXth century), or a process (the assembly line in the early XXth century) (Grove 1996, Isaacson 1998). We submit that IPM, as an idea, a process, and a collection of technological advances, represented a strategic inflection point in the agricultural sciences of the fourth quarter of the XXth century. The robust conceptual foundation of IPM projects its influence beyond the limits of crop protection. IPM has become a model for all other operational components of sustainable agri- 
culture (Kogan \& McGrath 1993). It is just a matter of time and dedication from those who believe in its potential for IPM to become a global reality in practice, as well as in theory.

\section{Literature Cited}

ANDEF. 1991. Associação Nacional de Defensivos Agricolas, São Paulo, SP, Brazil.

APO - Asian Productivity Organization. 1993. Pest control in Asia and the Pacific: report of an APO Seminar 24th September-4th October, 1991, Tokyo, Japan. Tokyo, Asian Productivity Organization, $409 \mathrm{p}$.

Aragon, J. 1991. El manejo integrado de plagas en soja. Desarrollo Argentino (Rosario), 8: 9-12.

Bajwa, W. I. \& M. Kogan. 1997. Compendium of IPM definitions (CID). Electronic Publication (http:// www.ippc.orst.edu/IPMdefinitions).

Balázs, K., G. Jenser \& G. Bujáki. 1996. Eight years' experiences of IPM in Hungarian apple orchards, p. 95-101. In F. Polesny, W. Müller \& R. W. Olszak (eds.), Proceedings of the International Conference on Integrated Fruit Production, Cedzyna, Poland, 28 August - 2 September 1995. Acta-Horticulturae, No. $422-443$ p.

Boza-Barducci, T. 1972. Ecological consequences of pesticides used for control of cotton insects in Canete Valley, Pern, p. 423-438. In M.T. Farvar \& J.P. Milton (eds.), The careless technology. New York, Natural History Press, 510p.

Braun, A.R., A.C. Bellotti \& J.C. Lozano. 1993. Implementation of IPM for smallscale cassava farmers, p. 103 - 115. In M. A. Altieri (ed.), Crop protection strategies for subsistence farmers. San
Francisco, Westview Press, Inc., 197 p.

Brown, A.W.A. 1958. Insecticide resistance in arthropods. Geneva, W.H.O., 240 p.

Campanhola, C., G. J.D. Moraes \& L.A.N. De Sa. 1995. Review of IPM in South America. p. 121-151. In A.N. Mengech, K.N. Saxena \& H.N.B. Gopalan (eds.), Integrated pest management in the tropiccurrent status and future prospects. New York, John Wiley \& Sons, 171 p.

Carson R. 1962. Silent spring, Boston, Houghton Mifflin, 368p.

Copping, L.G. (ed.). 1998. The Biopesticide manual. Surrey, U.K., British Crop Protection CouncilFarnham, 333 p.

Cousens, R. \& M. Mortimer. 1995. Dynamics of weed populations. Cambridge, New York, Cambridge University Press, 332 p.

Croft, B.A. 1990. Arthropod biological control agents and pesticides. New York, Wiley, $723 \mathrm{p}$.

Cross, J.V., A. Bonauer, V. Bondio, J. Clemente, J. Denis, J. Grauslund, C. Huguet, E. Jörg, S. Koning, A. Kvale, C. Malavota, R. Marcelle, I. Morandell, H. Oberhofer, M. Pontalti, F. Polesny, M. Rossini, A. Schenk, C. de Schaetzen \& M. Vilajeliu. 1995. The current status of integrated pome fruit production in western Europe and its achievements, p. 1-10. In F. Polesny, W. Müller \& R. W. Olszak (eds.), Proceedings of the International Conference on Integrated Fruit Production, Cedzyna, Poland, 28 August - 2 September 1995. Acta-Horticulturae. No. 422, 443 p.

Day, E. (ed.). 1998. Integrated Pest Management Measuring Systems Workshop. Chicago, Illinois, Amer. 
Farmland Trust. 191 p.

Escobar, G.J.A. 1986. Criterios para la evaluación de programas de manejo integrado de plagas, con referencia especial al caso en caña de azucar. In Conferencias Especiales 13. Congresso Socolen, 16 - 18 July 1986, Cali, Colombia, p. 64 - 97.

FAO, 1966a. Report of the FAO Symp. on Integrated Pest Control Rome, Oct. 1115, 1965,. Rome, Italy, FAO-UN, 40p.

FAO, 1966b. Proc. FAO Symp. Integrated Pest Control Rome, Oct. 11-15, 1965. Rome Italy, FAO-UN, Part 1, 91p., Part 2, 186p., Part 3, 129p.

FAO, 1993. Global IPM: a report on the global IPM field study tour and meeting August - September 1993. FAO, Manila.

FAO, 1994. Sustainable agriculture through integrated pest management. Presented at the $22^{\text {nd }}$ Regional Conference for Asia and the Pacific, Manila, 3 -7 October.

Fernandez, J. 1994. Pesticide use reduction assessment. Senate Committee on Agriculture, Nutrition, and Forestry, Washington DC. 12 p.

Fitt, G.P. 1994. Cotton pest management: Part 3. An Australian Perspective. Annu. Rev. Entomol. 39:543-62.

Garcia, F. 1990. Avances y perspectivas del control biologico en Colombia. Colombia Ciencia y Tecnologia, 8: 8 -12.

Geier P.W. 1966. Management of insect pests. Ann. Rev. Entomol. 11:471-490.

Geier P.W. \& L.R.Clark. 1961. An ecological approach to pest control. Proc. Tech. Meeting Intern. Union for Conserv. of Nature and Natural Res., $8^{\text {th }}, 1960$, Warsaw, 10-18.
Grove, A. 1996. Only the paranoid survive: how to exploit the crisis points that challenge every Company and Career. New York, Doubleday. 210 p.

Hall, F.R. \& J.J. Menn. 1999. Biopesticides: use and delivery. Totowa, New Jersey, Humana. 626 p.

Hansen, M. 1987. Escape from the pesticide treadmill. Consumers Union, 185p.

Higley, L.G. \& L.P. Pedigo (eds.). 1996. Economic thresholds for integrated pest management. Lincoln, Nebraska, Univ. of Nebraska Press, 327 p.

Hollingsworth, C.S. 1996. Extending the concepts of IPFP to other crops: an IPM certification program in Massachusetts, USA, p. 90-94. In F. Polesny, W. Müller \& R.W. Olszak (eds.), Proceedings of the International Conference on Integrated Fruit Production, Cedzyna, Poland, 28 August - 2 September 1995. ActaHorticulturae, No. 422, 443 p.

Iles, M.J. \& A. Sweetmore, A. (eds.). 1991. Constraints on the adoption of IPM in developing countries - a survey. Natural Resources Institute, Kent, UK.

Issacson, W. 1998. Man of the year. Time, Dec. 29, 1997-Jan. 5, 1998. p.48-51.

Jackai, L.E.N. \& R.A. Daoust. 1986. Insect pests of cowpea. Ann. Rev. Entomol. 31:95-119.

Kenmore, P.E. 1996. Integrated pest management in rice, p. 76-97. In G.J. Persley (ed.) Biotechnology and pest management. Wallingford, UK, CAB International, $475 \mathrm{p}$.

Kogan, M. 1988. Integrated pest management theory and practice. Entomol Exp. Appl. 49:59-70. 
Kogan, M. 1998. Integrated pest management: Historical perspectives and contemporary developments. Ann. Rev. Entomol. 43:243-270.

Kogan, M., B.A. Croft \& R.F. Suthurst. 1999. Applications of ecology for integrated pest management, p. 681-736. In C.B. Huffaker \& A. Gutierrez (ed.) Ecological Entomology, $2^{\text {nd }}$ edit. New York, Wiley.

Kogan, M \& J. D. Lattin. 1999. Agricultural systems as ecosystems. Chapter 1, in J.Ruberson, ed. Handbook of pest management. New York, Marcel Dekker. in press.

Kogan, M. \& D. McGrath. 1993. Integrated pest management: Present dilemmas and future challenges. Anais $14^{\circ}$ Congresso Brasileiro de Entomologia. Piracicaba, S.P., Brazil. p 1-16.

Leslie, A.R. \& G.W. Cuperus. 1993. Successful implementation of integrated pest management for agricultural crops. Lewis Publications, Boca Raton, Florida, USA, 193p.

Liu, S. \& Y. Piao. 1992. Biological Control in China. Paper presented at FAO Regional Expert Consultation on Biological Control of Plant Pests, 8 -12 July 1992, Hangzhou, People's Republic of China.

Mengech, A.N., K.N. Saxena \& H.N.B. Gopalan (eds.). 1995. Integrated pest management in the tropics- current status and future prospects. New York, John Wiley \& Sons, $171 \mathrm{p}$.

Metcalf, R.L. 1986. The ecology of insecticides and the chemical control of insects. p. 251-297. In M. Kogan (ed.) Ecological theory and integrated pest management practice. N.Y., Wiley, 362 p.
Michelbacher A.E. \& O.G. Bacon. 1952. Walnut insect and spider mite control in Northern California. J. Econ. Entomol. 45:1020-27.

Morse, S. \& W. Buhler. 1997. Integrated pest management: ideals and realities in developing countries. London, Lynne Rienner Publishers, 171 p.

Moscardi, F. \& D.R. Sosa-Gomez. 1996. Soybean in Brazil, p. 98 -112. In G.J. Persley (ed.), Biotechnology and integrated pest management. CAB International, UK.

NAS - National Academy of Sciences. 1969. Insect-pest management and control. Washington, DC: Nat. Acad. Sci. pub. 1695, $508 \mathrm{p}$.

Nel, P. J., M. F. Addison, A.M.E. Schenk, A.D. Webster \& S.J. Wertheim. 1993. The development of an integrated pest management programme in apple orchards in Elgin, South Africa and the implications for integrated fruit production. Second international symposium on integrated fruit production, Veldhoven, Netherlands, August 24-28, 1992, p. 323-326.

Ooi, P.A.C, G.S. Lim, T.H. Ho, P.L. Manalo \& J. Waage (eds.). 1991. Proceedings of the conference on IPM in the AsiaPacific Region, 23-27 September 1991, Kaula Lumpur, Malasia, 445 p.

Perkins, J.H. \& B.R. Patterson. 1997. Pest pesticides and the environment: A historical perspective on the prospects for pesticide reduction, p. 13-33. In D. Pimentel, Techniques for reducing pesticide use. N.Y., Wiley, 444 p.

Persley, G.J. (ed.). 1996. Biotechnology and integrated pest management.CAB Int.

Pretty, J.N. 1995. Regenerating agriculture: 
Policies and practice for sustainability and self-reliance. Washington, D.C., Joseph Henry Press, 320p.

Prokopy R.J. \& B.A. Croft. 1994. Apple insect management, p. 543-89. In R.L. Metcalf \& W.H. Luckmann (eds.) Introduction to Insect Pest Management, $3^{\text {rd }}$ Ed. New York, Wiley, 650p.

Rabb R.L. \& F.E.Guthrie (eds.) 1970. Concepts of Pest Management. Raleigh: N.C.State Univ., 242 p.

Raheja, K. 1995. Practice of IPM in South and Southeast Asia, p. 69-119. In A.N. Mengech, K.N. Saxena \& H.N. B. Gopalan (eds.), Integrated pest management in the tropics- current status and future prospects. New York, John Wiley \& Sons, $171 \mathrm{p}$.

Ramalho, F. S. 1994. Cotton pest management : Part 4. A Brazilian perspective. Annu. Rev. Entomol. 39:563-78.

Reed, A.N. 1993. Low or no chemical: will it work?, p. 135 - 144. In Proceedings of the Eighty-eighth Annual Meeting., Washington State Horticulture Association.

Reed, A.N. 1995. Responsible Choice: A systems approach to growing, packing, and marketing fruit, p. 68-78. In J. Hull Jr. \& R. Perry, The 125th Annual Report of the Secretary of the State Horticultural Society of Michigan for the year 1995.

Reed, A.N. \& P. Nelson. 1996. Reasonable choice - an IFP approach, p. 319- 320. In F. Polesny, W. Müller \& R. W. Olszak (eds.), Proceedings of the International Conference on Integrated Fruit Production, Cedzyna, Poland, 28 August - 2 September 1995. Acta-Horticulturae, No. 422.443 p.
Schaetzen, C. de. 1996. Integrated pest managemnt in Belgium orchards in 1995, p. 321-323. In F. Polesny, W. Müller \& R.W. Olszak (eds.), Proceedings of the International Conference on Integrated Fruit Production, 28 August - 2 September, 1995. Acta Horticulturae, No. 422,443 p.

Schafermeyer, S. 1991. Vergleichende Untersuchungen zu Richtlinien fur die integrierte Kernobstproduktion in Europa (Comparative studies on guidelines for integrated pome fruit production in Europe). Berlin, Kommissionsverlag P. Parey, 110 p.

Schwartz, P.H. \& W. Klassen. 1981. Estimate of losses caused by insects and mites to agricultural crops, p. 15-77. In D. Pimentel (ed.), Handbook of pest management in agriculture. Boca Raton, Florida, CRC Press Inc., 597p.

Servian de Cardozo, J.F. 1990. Problematica de las plagas y los plaguicidas en el sector campesino. In: Consulta Sudamericana sobre Manejo Integrado de Plagas en la Agricultura Campesina. Instituto Agronomico Nacional, Caacupe, Paraguay.

Soon, L.G. 1996. Integrated pest management in developing countries, $p$ 61-75. In G. J. Persley (ed.), Biotechnology and integrated pest management. Biotechnology in Agriculture, No. 15. Cab International, UK, 475 p.

Sorensen, A. A. 1998. Integrated pest management: future farming takes lessons from the past. Electronic Publication (http://ificinfo.health.org/insight/intpest.htm).

Sterling, W. 1984. Action and Inaction Levels in Pest Management. College 
Station, Texas, Texas Agr. Exp. Station. B-1480, $20 \mathrm{p}$.

Sugonyaev, E. S. 1994. Cotton pest management: Part 5. A Commonwealth of Independent State perspective. Annu. Rev. Entomol. 39:579-92.

Surgeoner, G.A. \& W. Roberts. 1993. Reducing pesticide use by $50 \%$ in the province of Ontario: challenges and progress. p. 206-222. In D. Pimentel \& H. Lehman (eds.), The Pesticide question : environment, economics, and ethics. New York, Chapman \& Hall. $441 \mathrm{p}$

Thompson, G. 1998. Industry and individual company's perspective on resistance management. Resistance Pest Management 9: 6-9.

Van den Bosch, R. 1978. The Pesticide Conspiracy. Garden City, N.Y., Doubleday, $226 \mathrm{p}$.

Vandeman, A., J. Fernandez-Cornejo, S. Jans \& B. Lin. 1994. Adoption of integrated pest management in U.S. agriculture. Resources and Technical Division, Economic Research Service, USDA. Agri. Info. Bull. No. 707.

Wardhani, M.A. 1991. Development in IPM: the Indonesian case. p.27-35. In P.A.C Ooi, G.S. Lim, T.H. Ho, P.L. Manalo \& J. Waage (eds.), Proceedings of the Conference on IPM in the AsiaPacific Region, 23-27 September 1991, Kaula Lumpur, Malasia.

Ware, G.W. 1986. Fundamental of pesticides: A self-instruction guide. Fresno, California, Thompson, $274 \mathrm{p}$.

Warner, G. 1998. People want IFP fruit, but are unwilling to pay more. Good Fruit Grower, 49(15): 22-23.

WRI - World Resource Institute. 1994.

World resources - a guide to the global environment; people and the environment; resource consumption; population growth; women. New York, Oxford University Press, 400p.

Zethner, O. 1995. Practice of integrated pest management in tropical and sub-tropical Africa: An overview of two decades (1970-1990). In A.N. Mengech, K.N. Saxena \& H.N. B. Gopalan (eds.), Integrated pest management in the tropics- current status and future prospects. New York, John Wiley \& Sons, $171 \mathrm{p}$.

Zhaohui, Z., P. Yongfan \& L. Juru. 1992. National integrated pest management of major crops in China, p. 255 - 66. In P.A.C. Ooi, G.S. Lim, T.H. Ho, P.L. Manalo \& J. Waage (eds.), Integrated Pest Management in the Asia-Pacific Region. CAB International, UK.

Zurawicz, F., A. Bielenin \& B.H. Labanowska. 1996. Preliminary scheme for IFP of soft fruit in Poland, p. 35-41. In F. Polesny, W. Müller \& R.W. Olszak (eds.), Proceedings of the International Conference on Integrated Fruit Production, 28 August - 2 September, 1995. Acta Horticulture, No. 422, 443p. 